Gönderim Tarihi: 22.06.2016 Kabul Tarihi: 17.02.2018

\title{
SAĞLIK KURUMLARINDA INSAN KAYNAKLARI ALANINDA YAPILAN ÇALIŞMALARIN İNCELENMESİ
}

\author{
Gülsün ERİGÜÇ* \\ Furkan ŞAHINBAŞ** \\ Şenol DEMIRCI' $\dot{I}^{* * *}$ \\ Gülcan ŞANTAŞ**** \\ INVESTIGATION OF THE STUDIES IN THE FIELD OF \\ HUMAN RESOURCES IN HEALTH CARE \\ ORGANIZATIONS
}

\begin{abstract}
$\ddot{O} z$
$\mathrm{Bu}$ çalışmada sağlık kurumlarında insan kaynakları alanında performans değerleme, kariyer, ücret, personel seçme ile ilgili çalışmaların tematik dağılımlarının ortaya konması amaçlanmıştır. Çalışma kapsamında 84 çalışmanın yapıldığı tespit edilmiştir. İçerik analizi ile konu dağılımı incelendiğinde, ücret $(\% 34,52)$ ve performans değerleme $(\% 28,57)$ konularının en çok çalışılan konular olduğu belirlenmiştir. Çalışma sonucunda, sağlık kurumlarında en az çalışılan konunun kariyer $(\% 11,90)$ olduğu ortaya konulmuştur. Toplamda 84 çalışmadan 54'ünün yüksek lisans tezi, 6'sının doktora tezi ve 24'ünün makale olduğu bulgusu elde edilmiştir. 1990-1995 yıllarında performans değerleme, kariyer, ücret, personel seçme ile ilgili yalnızca 2 akademik çalışma bulunmasına rağmen, 2011-2015 yılları arasında 40'a yükselmiştir. Çalışmaların araştırma örneklemine göre dağılımı incelendiğinde, en fazla hemşireler ve hekimler üzerinde araştırmaların yapıldığı belirlenmiştir. Araştırmaların büyük oranda anket tekniğiyle (68) yürütüldüğü saptanmıştır. İleride yapılacak çalışmalarda görüşme, gözlem gibi farklı yöntemlerin kullanılması, farklı bakış açılarını ve problem alanlarını belirlemede yardımcı olabilir. Sağlık kurumlarında insan kaynakları alanında özellikle doktora düzeyinde yapılacak nitelikli çalışmaların sayısının artırılması önerilebilir.
\end{abstract}

Anahtar Kelimeler: Performans Değerleme, Kariyer, Ücret, Personel Seçme, İnsan Kaynakları.

\footnotetext{
*Doç. Dr., Hacettepe Üniversitesi, İktisadi ve İdari Bilimler Fakültesi, Sağlık Yönetimi Bölümü, e-posta: geriguc@ hacettepe.edu.tr.

** Arş. Gör., Hacettepe Üniversitesi, İktisadi ve İdari Bilimler Fakültesi, Sağlık Yönetimi Bölümü, e-posta: furkansahinbas@ hacettepe.edu.tr.

${ }^{* * * *}$ Arş. Gör., Hacettepe Üniversitesi, İktisadi ve İdari Bilimler Fakültesi, Sağlık Yönetimi Bölümü, e-posta: senoldemrci@gmail.com.

***** Arş. Gör., Hacettepe Üniversitesi, İktisadi ve İdari Bilimler Fakültesi, Sağlık Yönetimi Bölümü, e-posta: gulcansantas@gmail.com.
} 


\begin{abstract}
This study aims to reveal the thematic distributions of performance evaluation, career, salary and personnel selection in the field of human resources in health care organizations. In the scope of the study, it was determined that 84 studies were made. When analyzing the content by content analysis, it was determined that the salary $(34.52 \%)$ and performance evaluation $(28.57 \%)$ were the most studied subjects. As a result of the study, it has been revealed that the least studied subjects were careers $(11,90 \%)$ in health care organizations. It was found that 54 studies were master's thesis, 6 studies were doctoral theses and 24 were articles from the total of 84 studies. Despite the fact that there were only 2 academic studies for individuals involved in performance appraisal, career, salary and staff selection between the years 1990-1995, it increased to 40 between the years 2011-2015. When the distribution of the studies was examined according to the research sample, it was determined that the researches were conducted mostly on the nurses and physicians. The researches were mostly carried out by the survey method (68). In the future studies, the use of different methods such as interviewing and observation can help to identify different aspects of the problem and problem areas. It may be suggested to increase the number of qualified works to be done especially at doctoral level in the field of human resources in health care organizations.
\end{abstract}

Keywords: Performance Appraisal, Career, Salary, Personnel Selection, Human Resources.

\title{
1. Giriş
}

İnsan kaynağı, bir organizasyonun varlığını koruması ve sürdürmesinde en temel unsurlardan biridir. Sağlık kurumları için düşünüldüğünde, insan kaynağı hizmetin kapsamının ve sunumunun önemli ölçüde belirleyicisidir. Sağlık hizmetlerinin etkili, verimli ve kaliteli şekilde sunumunda insan kaynağı önemli role sahiptir. Sağlık kurumlarında sunulan hizmet yüksek oranda uzmanlaşma gerektirdiğinden, işgücü diğer sektörlere göre daha pahalı bir kaynaktır. Sağlık hizmeti, kesintisiz sürdürülmesi ve çoğunlukla ekip çalışması gerektiren bir hizmet türüdür. Hataya toleransın sıfır olduğu sağlık kurumları için, insan kaynağından kaynaklanan bir hatanın maliyetleri çok daha yüksek olabilmektedir. Bu sebepler bir arada düşünüldügünde, sağlı kurumları için insan kaynağının niteliği ve yönetimi daha önemli hale gelmektedir.

Stratejik birer paydaş olan insan kaynağının organizasyonlarda ayrı bir uzmanlık dalı olarak incelenmesinin tarihi eskilere dayanmaktadır, ancak özellikle son yıllarda insan kaynăğnın kendi dinamizmini ve sorun alanlarını ortaya koyan akademik çalışma sayısı artış göstermektedir. Bu çalışmalar, insan kaynakları yönetiminin profesyonel bir şekilde yürütülmesine katkı sağlamaktadır. Sağlık kurumlarında da insan 
kaynağının yönetimine ilişkin sorun alanları bulunmaktadır. Sorun alanlarının objektif olarak ortaya konması ve bu sorunlara yönelik çözüm önerilerinin belirlenmesinde, bilimsel temeli olan niteliksel ve niceliksel çalışmalardan yararlanılmaktadır.

Lisansüstü çalışmaların derlenmesi, bir araştırmacıya genel eğilimler, kullanılan yöntemler ve konu seçimi gibi unsurlara ilişkin önemli bilgiler vermektedir. $\mathrm{Bu}$ araştırmalardan yola çıkan araştırmacılar, kendi araştırmalarına yönelik yaklaşımlarını değiştirme ya da geliştirme konusunda bazı izlenimler edinebilmektedir (Coşkun, Dündar ve Parlak 2014: 380). Bir konu ile ilgili yapılmış bilimsel tezlerin analiz edilmesi o konunun derinliği ve yaygınlığı hakkında bilgiler vermektedir ve incelenen alanın genel görünümünü ortaya çıkarabilmektedir (Göktaş ve Erdem 2006: 54).

Sağlık kurumlarında insan kaynakları alanında yapılan bilimsel çalışmaların incelenmesi, bu alandaki gelişmeleri ortaya koyması açısından önemlidir. Bu konuda yapılmış bilimsel çalışmaların envanteri çıkarılarak güncel eğilimler belirlenebilir. Yıllar içinde lisansüstü tez ve makalelerin seyri incelenerek, bu alandaki tarihsel gelişim ortaya konulabilir. $\mathrm{Bu}$ alanda yapılmış bilimsel çalışmaların mevcut durumu değerlendirilerek, üzerinde çok çalışılan konu başlıkları ve bilimsel olarak yeterince ele alınmamış konuların belirlenmesi sağlanabilir. Daha önce sağlık kurumlarında insan kaynakları yönetimi alanında yazılmış bilimsel çalışmalara ilişkin bu tür bir mevcut durum analizi yapılmadığından, bu çalışmanın alan yazına katkı sağlayacağı düşünülmektedir.

\section{Teorik Literatür}

İnsan kaynakları fonksiyonları ile ilgili olarak farklı sınıflandırmalar yapabilmektedirler. Genel olarak fonksiyonlar, insan kaynakları planlaması, işe alma ve yerleştirme, eğitim ve geliştirme, motivasyon yönetimi, iş ve işgören değerleme, ücret yönetimi, kariyer yönetimi ve geliştirme, özlük işleri, çalışma ilişkileri ve güvenlik fonksiyonu şeklinde sınıflandırılabilir. Bu çalışmada performans değerleme, personel seçme, kariyer yönetimi ve ücret yönetimi ele alınmaktadır.

\subsection{Performans Değerleme}

Performans kavramı en geniş anlamıyla birey ya da grubun belirli bir hedefe ulaşabilmek için önceden belirlenen kriterleri, ürettikleri mal veya hizmetlerle kalite ve sayısal olarak karşılama derecesidir (Ötün 2013: 124-125). Performans yönetimi, işletmelerin hedefleri doğrultusunda 
çalışıp çalışmadığını ortaya koyabilmek, işgören seçme ve yerleştirmede daha etkin olabilmek, geleceğe yönelik performansı değerlendirebilmek ve ticari hayatta kalabilmek için önemli bir insan kaynakları fonksiyonudur (Karahan ve Özgür 2011: 53).

Performans değerleme, çalışanların görev ve sorumluluklarının daha önceden belirlenen performans standartlarına göre analiz edilerek belirlenen standartlara ne ölçüde ulaşıp ulaşamadığının ölçülmesidir. Performans değerleme sayesinde işletmeler çalışanların iş davranışlarını ve başarılarını saptayarak gelecekte yaşanabilecek sorunlar için önlemler almasını sağlayacaktır (Aldemir, Budak ve Ataol 2004: 291; Erdoğan 1991: 153-156). Bir başka tanımda performans değerlemesi, kurumda görevi ne olursa olsun bireylerin çalışmalarının, etkinliklerinin, eksikliklerinin, yeterliliklerinin, fazlalıklarının ve yetersizliklerinin bir bütün olarak tüm yönleriyle gözden geçirilmesidir (Tengilimoğlu, Işık ve Akbolat 2012: 384).

Sağlıkta performans değerleme, sağlık hizmet sunucularının sunduğu sağlık hizmetinin etkililiğinin hizmeti alan birey tarafindan istenilen düzeyde olup olmamasıdır. Performans değerlendirmesine, sağlık hizmet sağlayıcılarının aktivitelerini yansıtan hizmet kalitesi, sağlık sistemindeki kaynaklar ve finansal görünüm dâhildir (Pransky, Benjamin ve Dembe 2001: 296).

\subsection{Personel Seçme Ve Personel Seçim Süreci}

İşletmenin amaçlarını gerçekleştirecek çalışanların bulunması, günümüzde önemli bir iş alanı olarak görülmektedir. Personel seçimi; nitelikli kişilerden oluşan bir aday grubu oluşturulması ve bu adaylar arasından işletmeye ve ilgili işe en uygun olanının seçilmesidir (Geylan 1992: 100). İşletmelerin başarısında, çalışanların beceri ve yeteneklerinin büyük rolü vardır. Böylelikle, işe alma sürecinde işletmelerin adayların eşsiz nitelikleri ile iş gereklerini optimum bir biçimde kıyaslama çabasına girmeleri gerekmektedir (Holley 1987: 202). Personel seçiminde işletmenin personel ihtiyacının nitelik ve nicelik yönünden en iyi şekilde karşılanması için, uygun yöntemlerden yararlanarak yeterli sayıda ve nitelikte çalışanı zamanında sağlama amacı güdülmektedir. Bu amaca ulaşmada eğitim, deneyim ve geçmiş iş performansı, fiziksel özellikler, kişisel özellikler ve kişilik gibi seçim kriterleri önemli olmaktadır (Ergeneli 2016: 128-129).

Aday başvurusu ve başvuruların kabulü, başvuru formu doldurulması, ön eleme görüşmesi, sinav (test) yapma, işe alma görüşmesi, geçmiş iş deneyim ve öğrenimin araştırılması, sağlık ve fiziksel muayene ve iş 
teklifi ve işe yerleştirme aşamalarından oluşan personel seçim sürecinde her işletmenin kendi bünyesine uygun görerek kullandığı yöntemler bulunmaktadır. Personel seçmede en çok tercih edilen yöntemler; mülakat (görüşme), psikolojik testler (yetenek testleri, kişilik envanteri, iş bilgisi testleri), değerlendirme merkezi ve referanstır (Yelboğa 2010: 232).

\subsection{Kariyer}

İş görenin çalışma hayatını anlatan bir süreç olarak tanımlanan kariyer, bireyin bir işi seçmesi ile başlamaktadır. Kariyer doğru planlanırsa, çalışana maddi imkânlar dışında saygınlık, başarma arzusu ve özgüven kazandıran bir sürece dönüşmektedir (Ergeneli 2016: 246). Bir başka ifadeyle kariyer, bireyin zaman içerisinde edindiği iş deneyimleri dizisi olarak ifade edilmektedir (Arthur, Hall ve Lawrence 1989: 8).

Kariyer yönetiminin kariyer geliştirme, planlama gibi unsurları bulunmaktadır. Kariyer planlama, çalışanların potansiyelini geliştirmeyi ve onların iş tatminini artırarak daha üretken olmalarına katkı sağlamayı amaçlamaktadır (Lyria, Namusonge ve Karanja 2017: 34). Kişinin meslek seçimi, iş arayışı, işe girişi, deneyim kazanması, terfi etmesi, bazı durumlarda iş değiştirmesi ya da farklı işlere yönelmesi kariyer planlamasının konusudur. Bu süreç aynı zamanda bireysel kariyer geliştirme sürecidir. Kurumsal kariyer geliştirme süreci ise; birey için planlanan kariyerin kurum içinde ve kurumun amaçları doğrultusunda değerlendirilerek, bireyin çalışan olarak gelişimi ve değerlendirilmesinin yapıldı̆̆1 süreçtir (Ergeneli 2016: 250).

\section{4. Ücret}

Ücret, çalışanlara hizmet karşılığında ödenen para şeklinde tanımlanmaktadır (Tortop vd. 201: 256). En geniş anlamı ile ücret, yaptıkları işten dolayı çalıştıkları işletme tarafından çalışanlara sağlanan para veya paranın ikamesi olabilen maddi karşılıklardır. Bir çalışana verilen ücreti temel (kök) ücret ve değişken ücret oluşturmaktadır. Temel ücret çalışanın üstlendiği işin değerine ya da iş için sahip olduğu beceri ve yetkinliklere göre belirlenen ve belli bir zaman boyunca verilmesi garanti edilmiş ücrettir. Değişken ücret ise çalışanın performansı ya da ekstra katkılarına göre temel ücret dışında verilen ilave ödemelerdir (Ergeneli 2016: 301).

İşgören açısından ücret, temel gelir kaynağı olması ve ekonomik gücü belirlemesinden dolayı önemlidir. Ücret çalışanın ve ona bağlı aile bireylerinin ya da bağımlı kişilerin neredeyse tüm ihtiyaçlarını karşılamada kaynak olma özelliği görmektedir. Ücret kavramı, 
organizasyonda çalışmaya istekli personel potansiyelini yaratmak, iyi personeli elde tutmak, personeli güdülemek gibi amaçlar için önemli bulunmaktadır (Can, Kavuncubaşı ve Yıldırım 1995: 247).

\section{Araştırma}

\subsection{Araştırmanın Amacı ve Önemi}

Bu çalışmada Türkiye'de sağlık kurumlarında insan kaynakları alanında yapılan çalışmaların tematik dağılımlarının ortaya konması amaçlanmıştır. Araştırma betimsel niteliktedir.

Sağlık kurumlarında performans değerleme, kariyer, ücret, personel seçme ile ilgili çalışmalar tespit edilerek, yazarlar tarafından belirlenen başlıklar doğrultusunda çalışmalara yönelik elemeler yapılmıştır. Eleme sonrasında çalışma kapsamında değerlendirilmeye alınan araştırmalar; yazarı, yayın yılı, araştırmanın ismi, türü, örneklem ve araştırmada kullanılan yöntemlere göre incelenmiştir.

\subsection{Araştırma Kapsamı}

Araştırma kapsamında performans değerleme, kariyer, ücret ve personel seçme ile ilgili Türkçe çalışmaların tümüne ulaşabilmek için YÖK tez tarama veri tabanı ve ULAKBİM elektronik veri tabanı taranmıştır.

Sağlık kurumlarında performans değerleme için "'hastane performans değerleme', “sağlı performans değerleme”, “iş tanımı", “iş değerlemesi", “performans yönetimi", "performans standartları", “"performans kriterleri', “performans hedefleri', “kritik olay tekniğii,', ' 'zaman etüdü'” ve 'hareket etüdü', anahtar kelimeleri kullanılmıştır.

Sağlık kurumlarında personel seçme için "'hastane işe alma”, "sağlık işe alma", "sağlık personel seçme', sağlık işgören seçimi', "hastane işgören seçimi", ' hastane personel seçme', "'hastane eleman seçme',

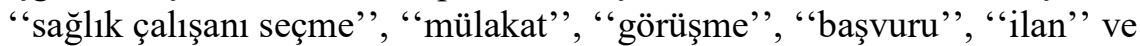
"'oryantasyon', anahtar kelimeleri dikkate alınmıştır.

Sağlık kurumlarında kariyer başlığı için aranan anahtar kelimeler ise, '“sağlık kariyer', ' 'hastane kariyer', 'sağlık kurumları kariyer', "'sağlık çalışanları kariyer', “doktor kariyer', ' hemşire kariyer”, "'sağl1k yöneticisi kariyer', "kariyer platosu', "meslek bilinci', ve " "terfi', dir.

Sağlık kurumlarında ücret için “ücret', “ücret sistemi', “ücret

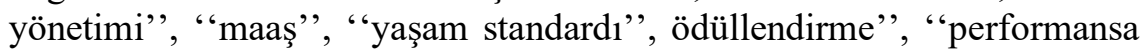


dayalı ücret', “ek ödeme', “sağlık ve ücret', “hastane ve ücret', kelimeleri ile arama yapılmıştır.

Sağlık kurumlarında "performans değerleme’, “personel seçme”, "'kariyer" ve "ücret' başlıklarının incelendiği bu çalışma, YÖK tez tarama veri tabanı ve ULAKBIM elektronik veri tabanına kayıtlı çalışmaları incelemektedir. Tarama sonucunda sadece makale, yüksek lisans ve doktora tezleri değerlendirilmeye alınmış olup; bu yayınların tam metinlerinin bir kısmına elektronik olarak ulaşılmıştır. Tam metinlerine ulaşılamayan yayınların büyük bir çoğunluğunu yüksek lisans ve doktora tezleri oluşturmaktadır.

$\mathrm{Bu}$ araştırmalara yönelik seçim kriterleri yazarlar tarafından oluşturulmuş olup belirlenen kriterler aşağıdaki gibidir:

Araştırmaların dilinin Türkçe olması ve Türkiye'de yapılmış olmas1

Tam metnine erişilebilir olması ya da tam metin yok ise özet kısmında araştırmanın örneklemi, yöntemi ve sonucuna yönelik bilgileri içeriyor olması

Sağlık çalışanlarına yönelik olması

Araştırmaların seçimine yönelik bilgilendirme Tablo 1'de yer almaktadır. Belirlenen kriterler kapsamında tam metnine ulaşılamayan 10 yayın ve bireysel olmayıp kurumsal konular ile ilgili olan 34 yayın elenmiştir. Yapılan tüm elemeler sonucunda 84 araştırma Şekil 1'de görüldügüü üzere çalışma kapsamında değerlendirilmeye alınmıştır.

Tablo 1: Çalışma Kapsamında Değerlendirilmeye Alınacak Araştırmaların Bilgisi

\section{Performans Değerleme Kariyer, Ücret, Personel Seçme ile alakalı yazılan toplam makale ve tez sayısı}

\section{Eleme Nedenleri}

n:128

1-Tam metine ulaşılamadı (Özet kısmından gerekli bilgilere ulaşılamadı) $\mathrm{n}: 10$

2-Bireysel olmayıp kurumsal konularla ilgili olan çalışmalar n:34

Elemelerden sonra değerlendirilmeye alınan makale ve tez sayısı n: 84 


\subsection{Araştırma Bulguları}

Çalışma kapsamında 2015 Aralık ayına kadar sağlık kurumlarında insan kaynakları yönetimi alanında 84 çalışmanın konularına göre dağılımı Tablo 2'de yer almaktadır. İçerik analizi ile incelenen tezlerin konu dağılım1 incelendiğinde ücret $(\% 34,52)$ ve performans değerleme $(\% 28,57)$ konularının en çok çalışılan konular olduğu görülmektedir. Sağlık kurumlarında en az çalışılan konunun kariyer $(\% 11,90)$ olduğu tespit edilmiştir.

Tablo 2: Sağlık Kurumlarında İnsan Kaynakları Yönetimi Alanında Yapılan Çalışmaların Konulara Göre Dağılımı

\begin{tabular}{|l|c|c|}
\hline Konu & Sayı & Yüzde \\
\hline Performans Değerleme & 24 & 28,57 \\
\hline Kariyer & 10 & 11,90 \\
\hline Ücret & 29 & 34,52 \\
\hline Personel Seçme & 21 & 25 \\
\hline Toplam & 84 & 100 \\
\hline
\end{tabular}

Sağlık kurumlarında insan kaynakları yönetimi alanında yapılan çalışmaların araştırma türüne göre dağılımı incelendiğinde toplamda 84 çalışmadan 54'ünün yüksek lisans tezi, 6'sının doktora tezi ve 24'ünün makale olduğu görülmektedir (bkz. Tablo 3).

Tablo 3: Sağlık Kurumlarında İnsan Kaynakları Yönetimi Alanında Yapılan Çalışmaların Araştırma Türüne Göre Dağılımı

\begin{tabular}{|l|c|c|c|}
\hline & \multicolumn{3}{|c|}{ Araştırma Türü } \\
\hline & $\begin{array}{c}\text { Yüksek } \\
\text { Lisans Tezi }\end{array}$ & Doktora Tezi & Makale \\
\hline $\begin{array}{l}\text { Performans } \\
\text { Değerleme }\end{array}$ & 16 & - & 8 \\
\hline Kariyer & 7 & - & 3 \\
\hline Ücret & 18 & 3 & 8 \\
\hline Personel Seçme & 13 & 3 & 5 \\
\hline Toplam & $\mathbf{5 4}$ & $\mathbf{6}$ & $\mathbf{2 4}$ \\
\hline
\end{tabular}

Sağlık kurumlarında insan kaynakları yönetimi alanında yapılan çalışmaların yıllara göre dağılımı incelendiğinde, yıllar içinde yapılan çalışma sayısında artış olduğu gözlenmektedir. 1990-1995 yıllarında yalnızca 2 akademik çalışma bulunmasına rağmen, 2001-2005 yıllarında bu say1 11'e, 2006-2010 yılları arasinda 30'a ve 2011-2015 yıllar1 arasında 40'a yükselmiştir. Konu dağılımlarına bakıldığında, 2011-2015 
y1lları arasında en çok çalışılan konunun ücret (22) olduğu belirlenmiştir (bkz. Şekil 1).

Şekil 1: Sağlık Kurumlarında İnsan Kaynakları Yönetimi Alanında Yapılan Çalışmaların Yıllara Göre Dağılımı

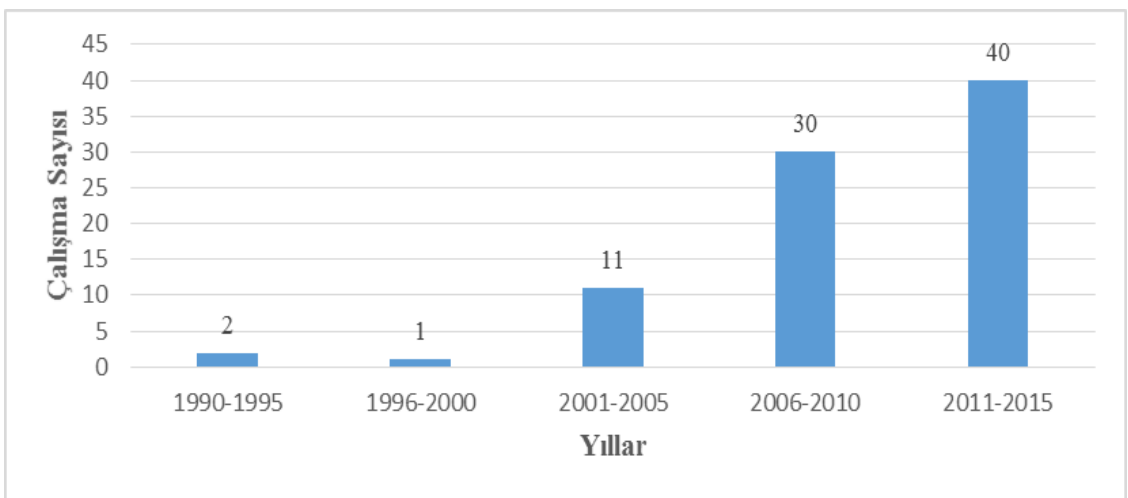

Sağlık kurumlarında insan kaynakları yönetimi alanında yapılan çalışmaların araştırma örneklemine göre dağılımı incelendiğinde, en fazla hemşireler ve hekimler üzerinde araştırmaların yapıldığı görülmektedir. Konu dağılımlarına göre incelendiğinde, hekimler üzerinde ücret (23), hemşireler üzerinde performans değerleme (15), hastane yöneticileri üzerinde personel seçme (8), yardımcı sağlık personeli üzerinde ücret (13), idari personel üzerinde ücret (8) ve öğrenciler üzerinde kariyer (3) konusu daha fazla çalışılmıştır (bkz. Tablo 4).

Tablo 4: Sağlık Kurumlarında İnsan Kaynakları Yönetimi Alanında Yapılan Çalışmaların Araştırma Örneklemine Göre Dağılımı

\begin{tabular}{|c|c|c|c|c|c|c|}
\hline & \multicolumn{6}{|c|}{ Araştırma Örneklemi } \\
\hline & Hekim & Hemşire & $\begin{array}{c}\text { Hastane } \\
\text { Yöneticileri }\end{array}$ & $\begin{array}{l}\text { Yardımcı } \\
\text { Sağlık } \\
\text { Personeli }\end{array}$ & $\begin{array}{c}\text { İdari } \\
\text { Personel }\end{array}$ & Öğrenci \\
\hline $\begin{array}{l}\text { Performans } \\
\text { Değerleme }\end{array}$ & 6 & 15 & 5 & 3 & 4 & - \\
\hline Kariyer & 2 & 6 & - & 1 & 1 & 3 \\
\hline Ücret & 23 & 12 & 7 & 13 & 8 & \\
\hline $\begin{array}{l}\text { Personel } \\
\text { Seçme }\end{array}$ & 3 & 7 & 8 & 4 & 4 & - \\
\hline Toplam & 34 & 40 & 20 & 21 & 17 & 3 \\
\hline
\end{tabular}

* Bazı çalışmalar, birden fazla katılımcı grubu üzerinde yapılmıştır.

Sağlık kurumlarında insan kaynakları yönetimi alanında yapılan çalışmaların araştırma yöntemine göre dağılımı incelendiğinde, araştırmaların büyük oranda anket tekniğiyle (68) yürütüldüğü 
görülmektedir. Anket tekniğinin yanı sıra görüşme (11), hastane bilgi sistemi (5), derleme (4) ve gözlem (4) teknikleri de kullanılmıştır (bkz. Tablo 5).

Tablo 5: Sağlık Kurumlarında İnsan Kaynakları Yönetimi Alanında Yapılan Çalışmaların Araştırma Yöntemine Göre Dağılımı

\begin{tabular}{|l|c|c|c|c|c|}
\hline & \multicolumn{5}{|c|}{ Araştırma Yöntemi } \\
\hline & Anket & Derleme & Görüşme & Gözlem & $\begin{array}{c}\text { Hastane } \\
\text { Bilgi } \\
\text { Sistemi }\end{array}$ \\
\hline $\begin{array}{l}\text { Performans } \\
\text { Değerleme }\end{array}$ & 21 & 1 & 3 & 2 & 1 \\
\hline Kariyer & 9 & - & 1 & - & - \\
\hline Ücret & 25 & 1 & 2 & 1 & - \\
\hline $\begin{array}{l}\text { Personel } \\
\text { Seçme }\end{array}$ & 13 & 2 & 5 & 1 & 4 \\
\hline Toplam & 68 & 4 & 11 & 4 & 5 \\
\hline
\end{tabular}

* Bazı çalışmalarda birden fazla araştırma yöntemi kullanılmıştır.

\section{Tartışma ve Sonuç}

Bu çalışmada Türkiye'de sağlık kurumlarında insan kaynakları alanında performans değerleme, personel seçme, kariyer ve ücret ile ilgili çalışmaların tematik dağılımlarının ortaya konması amaçlanmıştır. Çalışma kapsamında 84 çalışmanın yapıldığ 1 tespit edilmiştir.

İçerik analizi ile incelenen tezlerin konu dağılımı incelendiğinde ücret $(\% 34,52)$ ve performans değerleme $(\% 28,57)$ konularının en çok çalışılan konular olduğu belirlenmiştir. Ücret, yönetimde motivasyonu sağlayan en etkili araçlardan biridir (Soykenar 2008: 28). Çalışanın o kurumda çalışmayı kabul etmesi ve o işletmeye bağlanmasında ücret, en güçlü motivasyon özendiriciler arasındadır (Sabuncuoğlu ve Tüz 1998: 148). Ancak adil bir ücret sisteminin oluşturulmadığı sağlık kurumlarında çalışanlar sorun yaşamakta ve iş motivasyonları azalabilmektedir. Sağlık kurumlarının karmaşık ve dinamik doğası, ücret yönetimini daha önemli hale getirmektedir. Sağlık hizmetlerinin sunumunda farklı uzmanlıklara ve eğitim düzeylerine sahip birçok sağlık çalışanı rol almaktadır. $\mathrm{Bu}$ nitelikli insan gücüne en uygun ücret sisteminin oluşturulması, sağlık kurumları için zorlayıcı olabilmektedir. Performans değerlendirmesi, örgütler için anahtar bir faaliyet olup örgütün performansını artırma potansiyeline sahiptir (Bach, 2005: 289; Karimi ve Singh, 2004: 66). Bu çalışma, sağlık kurumlarının çalışanların ücret ve performans 
değerlendirme ile ilgili sorunlarını değerlendirmede bilimsel kaynaklara başvurduğunu göstermektedir.

Çalışma sonucunda, sağlık kurumlarında en az çalışılan konunun kariyer $(\% 11,90)$ olduğu ortaya konulmuştur. Dünya Sağlı Örgütü, sağlık insan gücü planlaması ile ilgili yeni yönelimin sağlı insan gücünü geliştirme olduğunu belirtmektedir. Sağlık insan gücü geliştirme, insan gücünün planlanması, üretimi (eğitimi) ve yönetimi, başka bir deyişle ihtiyaçların tespiti ve sağlık çalışanlarının gerektiği gibi eğitilmesi, istihdam edilmeleri, yeterli ücret almaları ve sağlı sisteminde kalmaları için kariyer gelişimi olanaklarını sağlayacak adımların atılmasıdır (Şantaş, Özer ve Çıraklı 2012: 49). Bu açıdan bakıldığında, sağlık kurumlarında insan gücü geliştirmenin önemli adımlarından birinin kariyer ve ilerleme fırsatları olduğu söylenebilir. Yapılan bir çalışmada, sağlık sektörü alanyazınında halef yetiştirme konusunun önemine değinilmektedir. Özellikle hemşire eksiği göz önünde bulundurulduğunda, örgütsel ihtiyaçları ve donanımlı hemşire yetiştirme talebini karşılayacak bir kariyer planlamasına ihtiyaç duyulmaktadır (Carriere vd., 2009: 548). Özellikle hekimlik mesleğinin kariyerine yönelik trendleri anlamak, meslek tatmininde önemli olmaktadır (Landon, Reschovsky ve Blumenthal, 2003: 442). Aksi durumda, kariyerinde tatminsizlik yaşayan hekimlerin yüksek kalitede hizmet sunması zorlaşabilmektedir (Stoddard vd., 2001: 675). Sağlık çalışanı, kariyer ve kişisel gelişim fursatları için, çalıştığı kurumda boş olan yönetici kadroları, bu kadrolara yeterlilik şartları, sertifika programları gibi konularda bilgilendirilmelidir. $\mathrm{Bu}$ bilgilendirmenin niteliği ve etkililiği, kurum içi ve dışında yürütülen bilimsel çalışmalarla desteklenmelidir. Sağlık sektörünün uzmanlaşma temelli yapısı göz önünde bulundurulduğunda, kariyer yönetimi, alanda bilgi birikiminin derinleşmesine katkı sağlayabilir. Kalkınma planlarında da kariyer mesleklerde nitelikli insan gücü istihdamının teşvik edileceğine değinilmektedir (Kalkınma Bakanlığı 2013). Bu sebeple, sağlık kurumlarında kariyer yönetimine yönelik çalışma sayısının artırılması önerilebilir.

Toplamda 84 çalışmadan 54'ünün yüksek lisans tezi, 6'sının doktora tezi ve 24 'ünün makale olduğu bulgusu elde edilmiştir. Ücret ve performans değerleme konuları hem yüksek lisans tezi olarak hem de makale olarak en çok çalışılmış konulardır. Çalışmalar incelendiğinde sağlık kurumlarında insan kaynakları yönetimi alanında yalnızca 6 doktora tezi olduğu belirlenmiştir. Gül, Yeşiltaş ve Keklik (2015: 242), sağlik yönetimi lisansüstü tezlerini inceledikleri çalışmasında, Ankara, Gazi, Hacettepe, Marmara, İstanbul, Dokuz Eylül gibi üniversitelerde belirli bir istikrar içinde tez yapıldığını; Atılım, Başkent, Cumhuriyet, Okan, 
Süleyman Demirel ve Ufuk üniversitelerinde ise son y1llarda tamamlanan tez sayısında artış olduğunu belirtmektedir. Bu çalışmanın sonucuna göre, insan kaynakları yönetimi alanında yapılan yüksek lisans ve doktora tezlerinin yeterli olmadığı düşünülmektedir. Türkiye genelinde üniversitelerin giderek artan sağlık yönetimi bölümleri lisansüstü eğitimlerine paralel olarak insan kaynakları yönetimi alanında tez ve makale sayısında artış olacağı beklenmektedir.

1990-1995 y1llarında performans değerleme, kariyer, ücret, personel seçme ile ilgili bireylere yönelik yalnızca 2 akademik çalışma bulunmasına rağmen, 2011-2015 yılları arasında 40'a yükselmiştir. Konu dağılımlarına bakıldığında, 2011-2015 yılları arasında en çok çalışılan konunun ücret (22) olduğu tespit edilmiştir. Türkiye'de 2004 yılı itibariyle, hekim ve sağlık personeline gerçekleştirdikleri iş karşılığında (muayene, ameliyat gibi) ek gelir elde etme imkânı sağlanmıştır. Bu sistem, sağlık hizmeti sunucularının emekleri karşılığında daha fazla gelir elde etmesi ve hastaların hizmete daha kolay ulaşması gibi amaçlarla uygulanmaktadır (Şantaş ve Kahraman 2017: 211). Sağlık kurumlarında son yıllarda ücret ile ilgili yapılan çalışmaların artışında, "performansa dayalı ek ödeme sistemi" ve bu uygulamaların kurumlara yansımalarının etkisinin olduğu düşünülmektedir.

Çalışmaların araştırma örneklemine göre dağılımı incelendiğinde, en fazla hemşireler ve hekimler üzerinde araştırmaların yapıldığ belirlenmiştir. Konu dağılımlarına göre incelendiğinde, hekimler üzerinde ücret (23), hemşireler üzerinde performans değerleme (15), hastane yöneticileri üzerinde personel seçme (8), yardımcı sağlık personeli üzerinde ücret (13), idari personel üzerinde ücret (8) ve öğrenciler üzerinde kariyer (3) konusu daha fazla çalışılmıştır.

Araştırmaların büyük oranda anket tekniğiyle (68) yürütüldüğü görülmektedir. Anket tekniğinin yanı sıra görüşme (11), hastane bilgi sistemi (5), derleme (4) ve gözlem (4) teknikleri de kullanılmıştır. Türkiye'de sağlık turizmi alanında yapılan lisansüstü tezlerin içeriklerinin değerlendirildiği bir çalışmada, tezlerin veri toplama araçlarının \%64'ünün anket yöntemi olduğu bulgusu elde edilmiştir (Bayın, 2015: 54). Bu çalışma sonucunda, kamu ve özel hastanelerin insan kaynaklarına yönelik bilgi paylaşım isteksizliğinin bu bulguyu ortaya çıkardığ söylenebilir. Özel hastaneler, performans değerleme, ücretlendirme gibi konularda hastane bilgi sistemine kayıtlı bilgilerin paylaşımından kaçınabilmektedir. Mahrem olduğu düşünülen bilginin paylaşılmamasının araştırmacıları alg1 ölçmeye yönelttiği ve bu amaçla da anket tekniğinin tercih edildiği düşünülmektedir. 
Sağlık kurumlarında insan kaynakları alanında yapılan bilimsel çalışmaların incelendiği bu çalışmadan elde edilen bulgular doğrultusunda ulaşılan sonuçlar ve bu sonuçlara yönelik geliştirilen öneriler şu şekilde özetlenebilir:

- Sağlık kurumlarında performans değerleme, kariyer, ücret ve personel seçme ile ilgili akademik çalışmaların daha çok yüksek lisans düzeyinde yapıldığ 1 ve doktora düzeyinde bu alanda çok fazla çalışmanın olmadığ tespit edilmiştir. Doktora düzeyinde yapılacak nitelikli çalışmaların sayısının artırılmasının organizasyonlar için önemli olduğu düşünülmektedir.

- Ücret konusunun en fazla çalışılan konu olarak belirlenmesi, bilimsel anlamda konunun problemli alanlarını ortaya koyması açısından önemli bulunmaktadır. Bilimsel olarak ortaya konulan bulguların hastane yöneticileri tarafından daha fazla kullanılması noktasında önerilerde bulunulabilir. Hastane yönetimleri, yönetimi zorlaştıran insan kaynağına ilişkin faktörlere çözüm önerileri geliştirmek amaciyla akademisyenlerden daha fazla destek almalıdır. Bununla birlikte, araştırmacıların üretilen bilimsel çalışmaların uygulanabilirliği ile ilgili daha yüksek düzeyde sorumluluk almaları beklenmektedir. Teorik olarak ortaya koydukları problem alanlarını iyileştirebilecek ve aynı metin içinde çözüm önerilerini de tartışabilecek bilimsel çalışmalara ihtiyaç duyulmaktadır.

- Sağlık kurumlarında kariyer konusu ile ilgili araştırma eksikliği, çalışmanın önemli bulgularından biridir. Bu konuda yapılacak çalışma sayısının artırılması önerilebilir. Kamu kurumlarında personel ihtiyacı, merkezi sınav yoluyla yapılmakta ve yeterli puanı alan sağlık elemanı belirtilen kadrolara atanmaktadır. Verilen hizmet içi eğitimler ve sertifika programları yoluyla çalışanın kendini geliştirmesi ve görevde yükselmesi mümkün olabilmektedir. Ancak, özel sağlık kuruluşlarının sayısının artması sebebiyle, özelde rekabet giderek şiddetlenmektedir. Nitelikli ve organizasyonla uyum sağlamış bir çalışanın işten ayrılıp başka bir kuruma geçmesi, organizasyon için hem parasal hem de manevi kayıp anlamına gelmektedir. Bu sebeple, organizasyonun çalışanlarını elinde tutabilecek ilerleme firsatlarını sunması beklenmektedir. Bu bağlamda, bu kurumlarda kariyer yönetimi uygulamalarında etkili olabilecek faktörlerin araştırılmasının önemli olduğu düşünülmektedir.

- Araştırma bulgularından hareketle, en çok kullanılan veri toplama tekniğinin anket olduğu ortaya konulmuştur. İleride yapılacak çalışmalarda görüşme, gözlem gibi farklı yöntemlerin kullanılması, sağlık 
kurumlarında insan kaynakları alanında farklı bakış açılarını ve problem alanlarını belirlemede yardımcı olabilir.

\section{Kaynaklar}

Aldemir, Ceyhan, Budak, Gönül ve Ataol, Alpay (2004). Insan Kaynakları Yönetimi. İzmir: Barış Yayınları Fakülteler Kitabevi.

Bach, Stephen (2005). Managing Human Resources: Personnel Management in Transition. 4th ed. Oxford: Blackwell.

Bayın, Gamze (2015). "Türkiye'de Sağlık Turizmi Alanında Yapılan Lisansüstü Tezlerin İçerik Değerlendirmesi”. Karamanoğlu Mehmetbey Üniversitesi Sosyal ve Ekonomik Araştırmalar Dergisi 2015(1): 49-55.

Bernard, Arthur Michael, Douglas, Hall and Barbara, Lawrence (1989). "Generating New Directions In Career Theory: The Case For A Transdisciplinary Approach". The Handbook of Career Theory. Ed. M.B. Arthur, D.T. Hall and B. Lawrence. New York: Cambridge University.

Carriere, Brian, Muise, Melanie, Cummings, Greta, Newburn-Cook, Chris (2009). "Healthcare Succession Planning: An Integrative Review". Journal of Nursing Administration. 39(12): 548-555.

Coşkun, İbrahim, Dündar, Şahin ve Parlak, Cansu (2014). “Türkiye’de Özel Eğitim Alanında Yapılmış Lisansüstü Tezlerin Çeşitli Değişkenler Açısından İncelenmesi (2008-2013)". Ege Eğitim Dergisi 15(2): 375-396.

Erdoğan, İlhan (1991). Işsletmelerde Personel Seçimi ve Başart Değerleme Teknikleri. İstanbul: İstanbul Üniversitesi.

Ergeneli, Azize (2016). Insan Kaynakları Yönetimi. Ankara: Nobel Akademik Yayınc1lı.

Geylan, Ramazan (1992). Personel Yönetimi, Eskişehir: Met Yayınevi.

Göktaş, Bayram ve Erdem, Ramazan (2006). "Sağlık Yönetimi Alanında Yapılan Tezlerin Profili”. Fırat Sağlık Hizmetleri Dergisi 1(1): 5363.

Can, Halil, Kavuncubaşı, Şahin ve Yıldırım, Selami (1995). Kamu ve Özel Kesimde Personel Yönetimi. Ankara: Siyasal Kitabevi.

Gül, İsa, Yeşiltaş, Aysun, Keklik, Belma (2016). "Sağlık Yönetimi Lisansüstü Programlarında Yapılan Tezlerin Profili". Mehmet Akif 
Ersoy Üniversitesi Sosyal Bilimler Enstitüsü Dergisi 1(13): 231244.

Holley, William H. and Jennings, Kenneth M. (1987). Personnel Human Resources Management Contrubutions and Activities. Chicago: Second Publishers.

Kalkınma Bakanlığı (2013). Onuncu Kalkınma Planı (2014-2018), Ankara.

http://www.kalkinma.gov.tr/Lists/Kalknma\%20Planlar/Attachment s/12/Onuncu\%20Kalk\%C4\%B1nma\%20Plan\%C4\%B1.pdf ${ }_{2} \quad 15$ Şubat 2017'de erişildi.

Karahan, Atila ve Özgür, Ersan (2011). Hastanelerde Performans Yönetim Sistemi ve Veri Zarflama Analizi. Ankara: Nobel Yayın Dağıtım.

Karimi, Sean, Singh, Gangaram (2004). "Strategic Compensation: An Opportunity for Union Activism", Compensation Benefits Review 36(2): 62-67.

Landon, Bruce, Reschovsky, James, Blumenthal, David. (2003). "Changes in Career Satisfaction Among Primary Care and Specialist Physicians, 1997-2001". Jama 289(4): 442-449.

Lyria, Rita Kagwiria, Namusonge, G.S. and Karanja, Kabare (2017). "The Effect of Career Management on Organizational Performance of Firms Listed in the Nairobi Securities Exchange". Journal of Human Resource and Leadership 1(3): 31-42.

Ötün, Tuba (2013). Kamu Sağlık Sektöründe Stratejik Yönetim Sürecinde Performans Ölçümü ve Değerlendirilmesi. Yüksek Lisans Tezi, İstanbul: Beykent Üniversitesi Sosyal Bilimleri Enstitüsü.

Pransky, Glenn, Benjamin, Katy and Dembe, Allard (2001). "Performance and Quality Measurment in Occupational Health Services: Current Status and Agenda for Further Research". American Journal of Industrial Medicine (40): 295-306.

Sabuncuoğlu, Zeyyat ve Tüz, Melek (1998). Örgütsel Psikoloji. Bursa: Alfa Kitabevi.

Sağlık Bakanlığı, Türkiye Halk Sağlığ 1 Kurumu. 2014 - 2017 Stratejik Plan1, http://thsk.saglik.gov.tr/eDosya/05/Stratejik_Plan_20142017.pdf, 15 Şubat 2017'de erişildi.

Soykenar, Mehmet (2008). Sağlık Işsletmelerinde Personelin Motivasyonunu Etkileyen Faktörler: Dokuz Eylül Üniversitesi 
Hastanesinde Örnek Bir Uygulama. Yüksek Lisans Tezi, İzmir: Dokuz Eylül Üniversitesi Sosyal Bilimleri Enstitüsü.

Stoddard, Jeffrey, Hargraves, Lee, Reed, Marie, Vratil, Alison (2001). "Managed Care, Professional Autonomy, and Income". Journal of General Internal Medicine 16(10): 675-684.

Şantaş, Fatih ve Kahraman, Gülcan (2017). "Sağlık Çalışanlarına Yönelik Algı: Hekim, Hemşire Ve Eczacının "Ekşi Sözlük"te Sunumu". Gümüşhane Üniversitesi Sosyal Bilimler Enstitüsü Elektronik Dergisi 8(19): 207-226.

Şantaş, Fatih, Özer, Özlem ve Çıraklı, Ümit (2012). "Türk Kalkınma Planlarında Sağlık İnsan Gücü Planlaması". Çankırı Karatekin Üniversitesi İktisadi ve İdari Bilimler Fakültesi Dergisi 2(2): 4559.

Tengilimoğlu, Dilaver, Işık, Oğuz ve Akbolat, Mahmut (2012), Sağllk İşletmeleri Yönetimi (4. Baskl). Ankara: Nobel Yayınları.

Tortop, Nuri vd. (2013). Insan Kaynakları Yönetimi (4.Baskl). Ankara: Nobel Yayın Dağıtım.

Yelboğa, Atilla (2010). Yönetimde İnsan Kaynakları Çalışmaları. Ankara: Turhan Kitabevi Yayınları. 